\title{
The Implementation of Scaffolding in Writing Recount Texts in SMP Joannes Bosco Yogyakarta
}

\author{
Tiara Maria Dewi and Yuseva Ariyani Iswandari \\ Sanata Dhrama University
}

\begin{abstract}
There are some compulsory subjects in junior high schools and English is one of them. As a compulsory subject, English needs to be mastered by the students. Therefore, English teachers are required to teach it well so that the students are able to master English. In teaching English, there is a need to use new techniques. Teachers need to vary the teaching techniques so that the students can learn English in different ways. One of the new techniques in teaching English is scaffolding. In this research, scaffolding is implemented in English class of the $8^{\text {th }}$ grade students of SMP Joannes Bosco Yogyakarta when they learn about recount text. This research aims to find out the process of how scaffolding is implemented and to know what the benefits of scaffolding in writing recount text. There were two research problems. The first was "How is scaffolding for the $8^{\text {th }}$ grade students of SMP Joannes Bosco in writing a recount text?" and the second was "What are the benefits of scaffolding in writing a recount text in SMP Joannes Bosco Yogyakarta?" The writers conducted a descriptive qualitative research in this study. The data was gathered by interviewing the English teacher, writing on the field notes, distributing the questionnaires, and interviewing the students. Analyzing the students' writings was used as the supplementary data to make the result stronger. The result of this study showed that the implementation of scaffolding gave benefits for the students. The benefits were challenging the students through deep learning and discovery, engaging the students in meaningful and dynamic discussions in the small and the large classes, and motivating the learners to become better students. In conclusion, scaffolding does give benefits for the students so that teachers are able to use scaffolding as one of the effective teaching techniques.
\end{abstract}

Keywords: scaffolding, writing, recount text, SMP Joannes Bosco

\section{Introduction}

Nowadays, English has been a language for international communication. As the international language, it is common that most of companies require the workers to have good skills in English so that they can build wider relation with other companies. It shows that English has become a need for people all around the world. Since it has become a need, there are many countries, such as Indonesia, that put English as one of the compulsory 
subjects in schools. It is taught from the elementary schools, the junior high schools, and the senior high schools. As the compulsory subject, the students are required to master English. There are four English skills that should be mastered, such as reading, writing, listening, and speaking (Bright \& McGregor, 1973). Usually, writing skill is emphasized in learning English because it is stated in the curriculum that the students need to be able to write some texts in English. Therefore, the teachers are also required to teach well because they need to make the students master English.

When the students learn to write, they need others' feedbacks so that they can write well. Providing feedback is the teacher's technique to teach writing for the students in SMP Joannes Bosco. The teacher usually provides feedback in the form of checking the incorrect sentences that the students write. The teacher also explains the incorrect sentence generally in the class. However, before the teacher requires the students to write the text, the teacher provides some of the same text types so that the students get the model of the text. The students can observe the language feature and also the generic structure of the text by reading the text given. The teacher gives more exposures to the language feature by giving an exercise to fill in the blank on the text.

This way of teaching needs to be improved. The students already get the model of the right texts, are also given the feedback for their writing, and get further general explanation in the class. Yet, they do not get the individual further explanation which makes the feedback more spesific and focus. The students also need to get a chance to write more than once so that they can really know how to write well. Therefore, there is a need to use new techniques in teaching writing.

One of the new teaching techniques that can be implemented is by using scaffolding. Scaffolding means providing the help for the students to support their learning process. The help is in the form of others' assistance. Since the writers see that there is a need to use a new technique in teaching the students in SMP Joannes Bosco, in this research, scaffolding is implemented when they learn the recount texts. Scaffolding is a technique to help the students. Therefore, it is expected that scaffolding could really help the students in writing a recount text well. The writers would like to see how it is implemented and what benefits of scaffolding in writing recount text in SMP Joannes Bosco.

\section{Review of Related Literature}

In this section the writers provide the theories that support this research. There are three key topics in this section. They are (1) Scaffolding, (2) Writing, and (3) Recount text.

\section{Scaffolding}




$\begin{array}{cl}\begin{array}{r}\text { Scaffolding is a teaching } \\ \text { technique to help students by }\end{array} & \begin{array}{l}\text { toward independence (Hyland, } \\ \text { 2003). } \\ \text { providing assistance from adult or }\end{array} \\ \text { more capable peers. Scaffolding was } & \text { Scaffolding for students can be } \\ \text { invented by Lev Vygotsky. The main } & \text { in the form of providing things like } \\ \text { point of scaffolding is to provide } & \text { mindmaps, etc. and guiding students } \\ \text { help or assistance for the learners in } & \text { in their learning process. Besides, } \\ \text { learning something. The assistance } & \text { there is another type of scaffolding } \\ \text { allows the students to be independent } & \text { which is not in the form of tools in } \\ \text { learners as what Slavin (2012) states: } & \text { helping the students. It is in the form } \\ \text { Scaffolding is the support for } & \text { of guidance for the students'learning } \\ \text { learning and problem solving; } & \text { process. This type is developed by } \\ \text { might include clues, } & \text { Frey, Fisher, and Everlove as cited in } \\ \text { reminders, encouragement, } & \text { Komalasari and Iswandari (2014). } \\ \text { breaking the problem down } & \text { This type requires the students to } \\ \text { into steps, providing an } & \text { become independent learners. An } \\ \text { example or anything else that } & \text { independent learner requires an } \\ \text { allows the student to grow in } & \text { independent learning which means } \\ \text { independence as a learner (p. } & \text { that the students can do the learning } \\ \text { 42). } & \text { process by themselves, without the } \\ \text { teachers' guiding. Similar with Frey, } & \text { Fisher, and Everlove, Nothern } \\ \text { The aim to involve scaffolding in the } & \text { Illinois University, Faculty } \\ \text { students' learning process is to make } & \text { Development and Instructional } \\ \text { them independent learners so that } & \text { Design Center (n.d.) also states the } \\ \text { they are able to accomplish task by } & \text { same. Figure 1 is the figure of } \\ \text { themselves. Teachers provide input } & \text { scaffolding model: } \\ \text { and instruction that support and } & \end{array}$




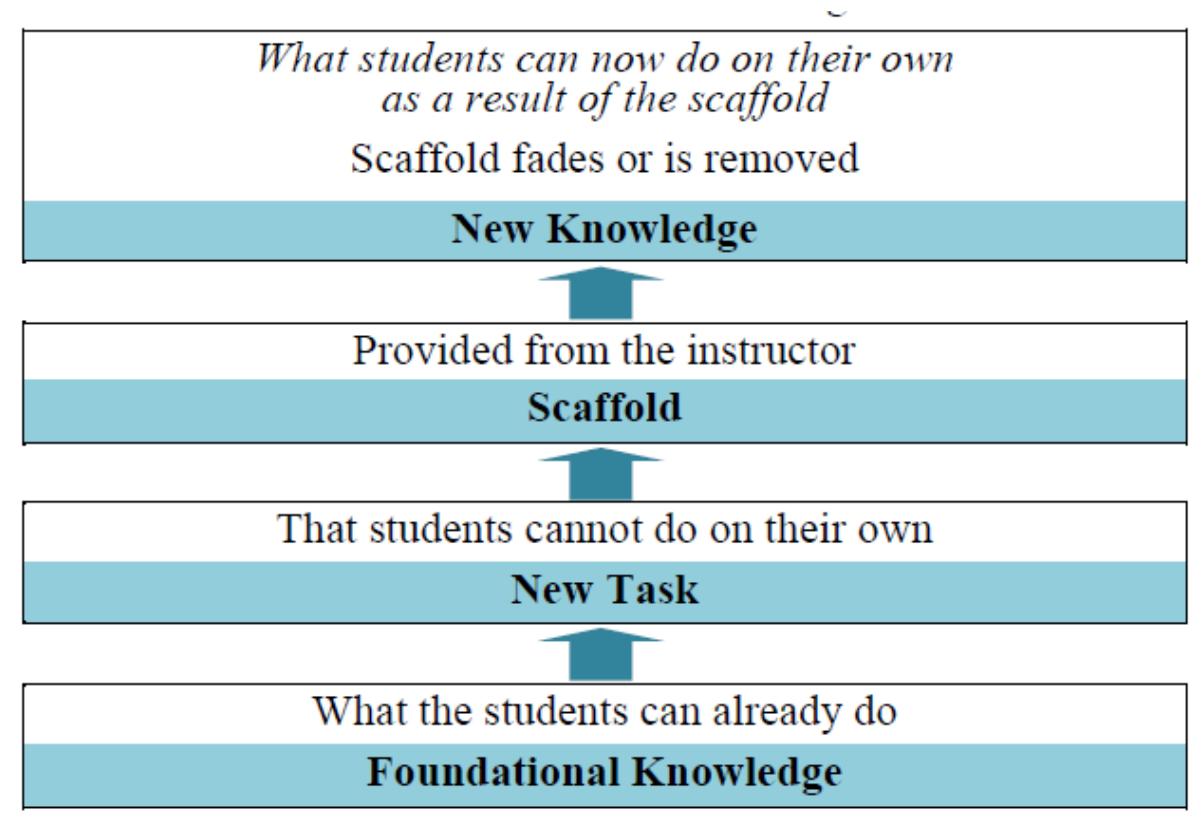

Figure 1 Models of Scaffolding

Adapted from: Nothern Illinois University, Faculty Development and Instructional Design Center (n.d.)

As figure 1 shows, scaffolding is implemented when the students cannot do the task on their own. As a result of the scaffolding implementation, students can do the task on their own. At this time, scaffolding is removed. Students do not need assistance anymore for their learning process.

Implementing scaffolding in the learning process gives some advantages. A study of Instructional Scaffolding to Improve Learning by Nothern Illinois University, Faculty Development and Instructional Design Center (n.d.) presents a proof that the instructional scaffolding has some advantages. They are: (1) Challenging students through deep learning and discovery, (2) Engaging students in meaningful and dynamic discussions in small and large classes, and (3) Motivating learners to become better students

\section{Writing}

According to Besserat and Errad (2008), writing is a general term for a visual system distinct from art, and a mode of language use that is distinguished from speaking, whereas writing system refers to a spesific type of graphic marks that represent types of linguistic units. Since writing deals with linguistic units, it means that writing includes grammars. Hyland (2003) states that writing is seen as a product constructed from the writer's command of the grammatical and 
lexical knowledge. Writing aims to share ideas and thought. According to Butt et al., (2000) as cited in Hyland (2003), there are five factual genres in writing. They are: (1) Recount, which tells about past experience, (2) Procedure, which tells a process of how something is done, (3) Description, which describes an imagined or factual events or things, (4) Report, which presents factual information about a class of things, usually by classifying them and describing their characteristics, and (5) Explanation, which gives reasons for something.

\section{Recount Text}

Recount texts are texts about past events or a text which retells past events, usually they are written orderly (Anderson, 1997 as cited in Indah, 2010). They tell about something in the past. According to Hyland (2003), the generic structure of a recount text is an orientation, a record of events, and a reorientation. In the orientation, there are informations about who, when, and where or the background information of the text (Government of South Australia, 2012). In a record of events, it is usually recounted in a chronological order. Government of South Australia (2012) uses different terms. They use sequence of events but the content is the same. There are series of events in a chronological order. Writers are able to express their feelings in this part. "It is appropriate to include personal comments and evaluative remarks throughout the text" (Government of
South Australia, 2012). The last part of the generic structure in recount text is reorientation. It is a summary of the whole text. Hyland (2003) stated that a reorientation rounds off the sequence of events.

By writing a recount text, people can share their personal experiences. People can be amused to listen to the story. As in Government of South Australia (2012) writes that recount texts are "used to relate experiences or retell events for the purpose of informing, entertaining or reflecting". Moreover, according to Hyland (2003), the purpose of a recount text is "to relate a sequence of events so that it entertains" (p.124).

\section{Methodology \\ Subject}

In this research, there were students of SMP Joannes Bosco and English Language Education Study Program (ELESP) students of Sanata Dharma University as the participants. The ones who scaffolded the students' writings were the ELESP students and the ones who were scaffolded were SMP Joannes Bosco students. The writers chose one class (VIII Happiness) in this study. There were twenty eight students in this class in the academic year 2014/2015. ELESP students were from class $C$ batch 2013 class Critical Reading and Writing (CRW) II. The writers chose students of CRW II because they have been majoring English Language Education Study Program (ELESP) for two years. It means that they are 
considered as more capable students as they are the ones who scaffold the SMP Joannes Bosco students' writings. There were fourteen students who were at the same level of writing skill. The ELESP students' A score on CRW I were the base to choose the fourteen students. Since there were fourteen ELESP students, one student of ELESP got two writings of class VIII Happiness to be checked. The ELESP students checked the errors in the use of verbs.

\section{Data Collection}

Before conducting the research, the writers gathered the data about the technique that the teacher usually used in teaching a recount text to the students and the process of implementing the scaffolding in writing a recount text in the $8^{\text {th }}$ grade Happiness SMP Joannes Bosco. After having enough information about the process of implementing the scaffolding, the writers distributed the questionnaires to the students after they wrote the recount texts three times. After analyzing the data in the questionnaires, the writers interviewed some students to clarify some questions that they answered unclearly. Then, the writers described the data and analyzed them to see what the benefits of implementing scaffolding.

\section{Result and Discussion}

In this part, the writers answer the research questions. The research questions are: 1) How is scaffolding implemented for the $8^{\text {th }}$ grade students of SMP Joannes Bosco in writing a recount text? 2) What are the benefits of scaffolding in writing a recount text for the $8^{\text {th }}$ grade students of SMP Joannes Bosco Yogyakarta? This part is divided into two sections. The first section is the process of scaffolding implemented for the $8^{\text {th }}$ grade students of SMP Joannes Bosco in writing a recount text. The second section is the benefits of scaffolding in writing a recount text for the $8^{\text {th }}$ grade students of SMP Joannes Bosco Yogyakarta.

The Process of Scaffolding Implemented for the $8^{\text {th }}$ Grade Students of SMP Joannes Bosco in Writing a Recount Text

The process of scaffolding that was implemented for the $8^{\text {th }}$ grade students of SMP Joannes Bosco in writing a recount text was related to the model of scaffolding process that was adapted from Nothern Illinois University, Faculty Development and Instructional Design Center (n.d.). Figure 2 presented the model. 


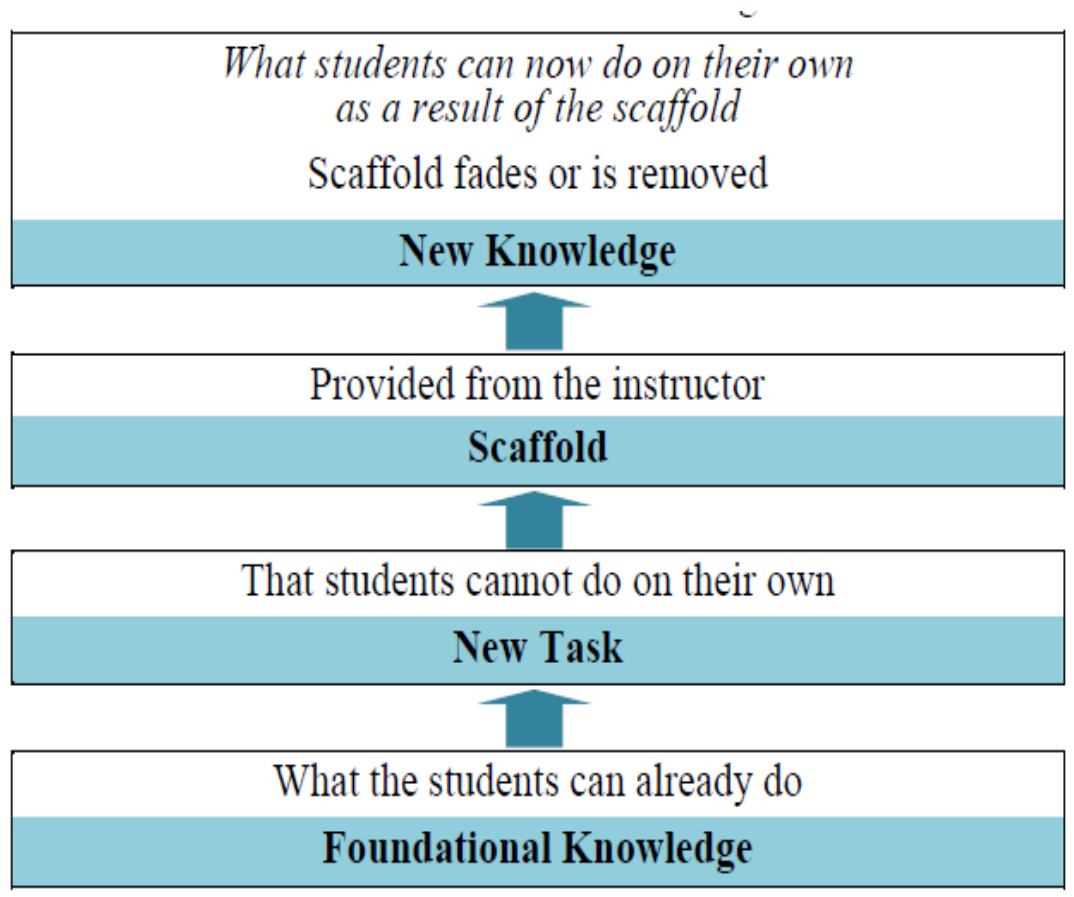

Figure 2 Models of Scaffolding

As Figure 2 showed, as the foundational knowledge, there was 'what the students can already do'. In this stage, the students were already able to do task that the teacher required them to do. In relation to this research, what the students could already do was they already knew how to write a recount text. It was because the teacher already explained about a recount text briefly to the students. After the teacher had already explained it, the students began to write their first recount texts. When they wrote their first recount text, they still made some errors related to the use of verbs in their writings. It was related to the 'new task' stage, where 'students cannot do on their own'.
Students needed others' assistance to help them writing a good recount text. In other words, they need scaffolding.

The role of ELESP students was as the scaffolders. They were included in the stage where 'provided from the instructor' was done. In this stage, scaffolding was done twice. The students' first writings were scaffolded by the ELESP students. The ELESP students scaffolded the writings by checking only the use of verbs in the students' recount texts. They found that the students still made some errors. They revised the inappropriate verbs and then they gave a letter to explain how the verbs should be corrected and gave spirit to 
the students. They wrote the letter themselves. Figure 3 presents the Student 12 first writing that had been checked by the ELESP student and the scaffolding from ELESP student in the form of letter.

Let ree tell you about my experience in bali. I went to $n$ bali at december $13^{\text {th }}$. I went with my friends and teachers. In balli i went to tanah lot. This place is very beautiful. in very excited : In thris place. 4 fook a picture and played with my frrends. 1 Interviessed the tourist for my engligh task. I saw the occean. He wave (15) very big. After that. (1) back to Yogyakarta by thebus. I was very happy.

1. was

2. was

3. was

4. Come back 


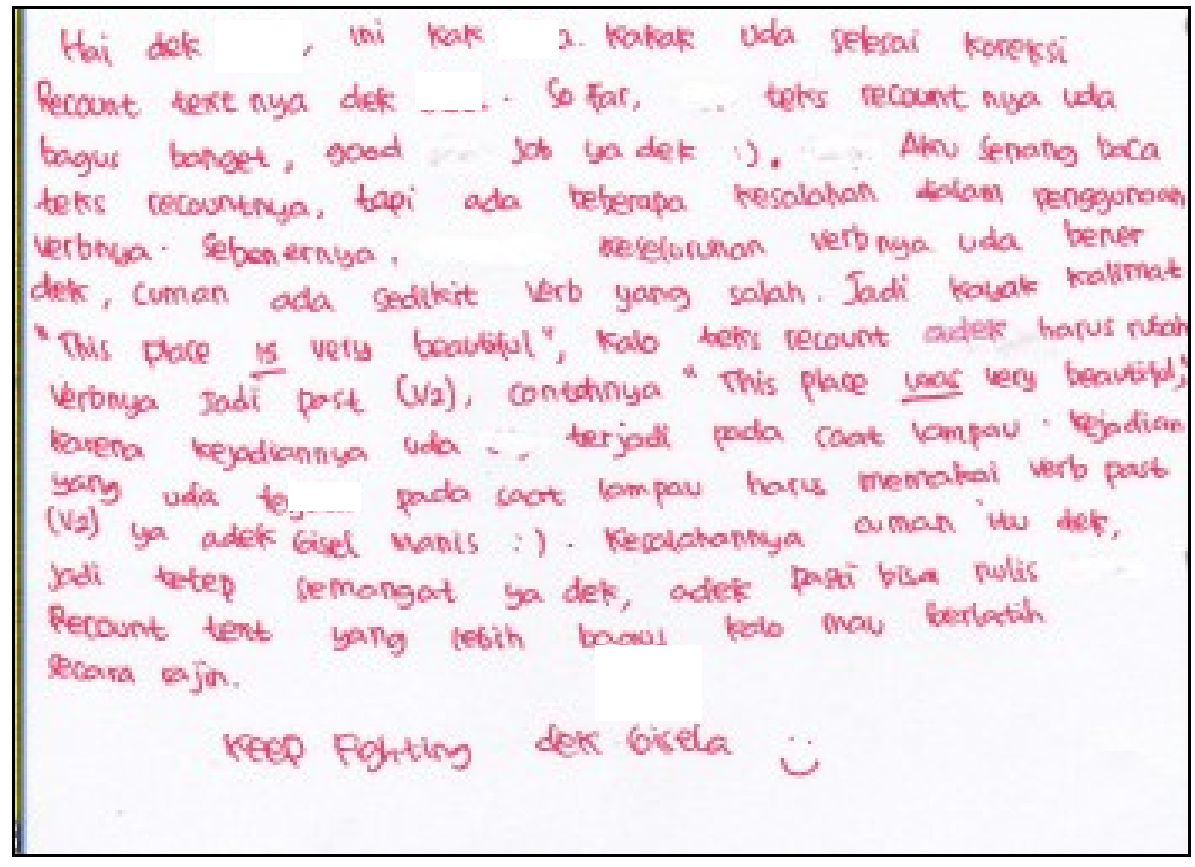

Figure 3 Student 12 First Writing and Scaffolding in the Form of Letter

Before the students wrote their second writings, they read the letter from the ELESP students. They respond it in some ways. There were some students who were very excited to get a letter from the ELESP students. They asked their friends who gave them the letter, or asked their friends whether the ELESP students were girls or boys. Some students seriously read the letter and some other students asked the teacher about the explanation because they did not understand. After they had already done reading the letter and paid attention to their first writing, they checked which words were right and wrong. Then, they started writing their second recount text. After that, those writings were delivered to the
ELESP students. When the ELESP students read their writings, they found that the students had some improvements. They began to write the correct form of the past form of the verbs.

After the students had been through the scaffolding process, they came to the stage "what students can now do on their own as a result of the scaffold'. In this stage, scaffolding was removed. The students were already able to write their recount texts alone with more awareness to the use of verbs. It could be seen that the student became aware of their previous errors and tried not to make the same errors again. In the third writing, most of the students got fewer errors than the first and the second writing. 
The students already became independent learners. The assistance allowed the students to be independent learners. It is related to Slavin's statement (2012):

Scaffolding is the support for learning and problem solving; might include clues, reminders, encouragement, breaking the problem down into steps, providing an example or anything else that allows the student to grow in independence as a learner ( $\mathrm{p}$. 42).

After scaffolding was implemented in the class, the students became independent learners. They became aware with the use of verbs when they wrote their second and third recount texts.

The Benefits of Scaffolding in Writing a Recount Text for the $8^{\text {th }}$ Grade Students of SMP Joannes Bosco Yogyakarta

When scaffolding was implemented in a writing recount text for the $8^{\text {th }}$ grade students of SMP Joannes Bosco Yogyakarta, it could give some benefits. The benefits were related to the scaffolding benefits that was stated by Illinois University, Faculty Development and Instructional Design Center (n.d.). The first benefit that was challenging students through deep learning and discovery. The second benefit was engaging students in meaningful and dynamic discussions in the small and the large class. The last benefit was motivating learners to become better students.

a. Challenging Students through Deep Learning and Discovery

With the guidance or tools to help students to learn, students had more exposures to the material given. They paid more attention and they could discover things related to the material so that they got better understanding. In relation with the findings on this research, the deep learning that the students had was the more exposures to write recount texts. The students wrote the recount text three times. They were also exposed to the use of verbs since the ELESP students checked the use of verbs. The exposures given made the students discovered things in a writing recount text. They became aware on the use of verbs.

\section{b. Engaging Students in Meaningful and Dynamic Discussions in Small and Large Class}

The next benefit was engaging students in meaningful and dynamic discussions in the small and the large class. By using the type of scaffolding, which was using guidance for students, students could have meaningful and dynamic discussion because they could get feedback for their learning process. In the research findings, each of the students got feedback from the ELESP students in the form of checking the incorrect verbs and writing the explanation in the form of a letter. The feedback was not 
only discussed generally in the class, but each of student had the further explanation of their writings. The ELESP students' scaffolding in the form of letter made the feedback became in a discussion. Even though it was not a direct discussion, the students got the feedback that focused on their own writings. As a result, the students still got the meaningful and dynamic discussion with the ELESP students since they could also really know why the verbs they wrote were wrong because there was explanation for it on the letter. Using scaffolding in the recount text gave the students opportunity to have individual feedback.

c. Motivating Learners to Become Better Students

The last benefit was motivating learners to become better students. Scaffolding also made students motivated in learning because the scaffolder could give motivation for the students to learn. Besides, the students could get individual feedback so that they really knew their errors. From the questionnaire, students agreed that scaffolding motivated them to learn English. It was because they could know their errors and know why it was wrong so that they would avoid making the same errors again. Therefore, the feedback that the ELESP students wrote motivated the students.

\section{Conclusion}

Based on the research findings, how scaffolding implementation is, the first, the teacher gave explanation about a recount text to the students. After that, the students began to write their first recount text. Having finished with the recount text, their writings were scaffolded by the ELESP students by checking the use of verbs and writing the explanation in the form of a letter. Before the students wrote their second writing, they got their writings back along with the ELESP students' explanation which was in the form of a letter for each of them. The students paid attention to their errors and read the explanation. After that, they wrote their second writing. Their second writings were scaffolded again by the ELESP students and they were delivered back to the students. The last, students wrote their third writings as the final product.

For the second research problem, scaffolding gives benefits to the students. There are three benefits after the implementation of scaffolding. The benefits are challenging students through deep learning and discovery, engaging students in meaningful and dynamic discussions in the small and the large classes, and motivating learners to become better students. In conclusion, scaffolding benefits the students.

This research proves that scaffolding gives benefits for learning writing a recount text. The writers suggest that teachers can use scaffolding as one of their techniques in teaching writing for students. It does not only able to help the students, but it is interesting for them 
because it is a new thing for them. Scaffolding does not only need seniors as the ones who scaffold. It can also be done by the students' friends. Therefore, it is also suggested that scaffolding among students is also implemented.

\section{References}

Besserat, D. S. \& Errad, M. (2008). Handbook of research on writing. New York: Lawrence Erlbaum Associated.

Bright, J.A., \& McGregor, G. P. (1973). Teaching English as a second language. London: Longman Group.

Government of South Australia. (2012). Engaging in and exploring recount writing : A practical guide for classroom teachers. Department for Education and Child Development, Government of South Australia.

Hyland, K. (2003). Second language writing. Cambridge: Cambridge University Press.

Indah, D. (2010). An undergraduate thesis on: Improving writing recount text by using photographs: Case study of the eleventh year students of SMAN 1 Pati in the academic year of 2009/2010. Semarang: IKIP PGRI Semarang. Retrieved August 2015, from https://andynuriman.files.wordpress.com/2011/10/skripsi_dwi-nurindah.pdf

Komalasari, A., \& Iswandari, Y. A. (2014). Proceedings of language and language teaching conference: Employing scaffolding strategy to facilitate students with different English circumstances. Sanata Dharma University, Yogyakarta: English Language Education Study Program.

Nothern Illinois University, Faculty Development and Instructional Design Center. (n.d). Instructional scaffolding to improve learning. Retrieved October $25^{\text {th }}$, 2014, from http://www.niu.edu/facdev/resources/guide/ strategies/instructional_scaffolding_to_improve_learning.pdf

Slavin, R.E. (2012). Educational psychology: Theory and practice $\left(10^{\text {th }}\right.$ ed.). Boston: Pearson Education. 